\title{
CHEMOSPHERE
}

\section{Interannual patterns of variation in concentrations of trace elements in arms of Octopus vulgaris}

\author{
Sónia Seixas ${ }^{\mathrm{a}, *}$, Paco Bustamante ${ }^{\mathrm{b}, 1}$, Graham J. Pierce ${ }^{\mathrm{c}, 2}$ \\ a Ciencias Exactas e Tecnologicas, Universidade Aberta, Rua Escola Politecnica, 147 1269-001 Lisbon, Portugal \\ ${ }^{\mathrm{b}}$ Laboratoire de Biologie et Environnement Marins, FRE 2727 du CNRS, Université de La Rochelle, \\ 22, Avenue Michel Crépeau, F-17042 La Rochelle Cedex, France \\ ${ }^{\mathrm{c}}$ Department of Zoology, School of Biological Sciences, Tillydrone Avenue. Aberdeen AB24 2TZ, United Kingdom
}

Received 28 June 2004; received in revised form 28 November 2004; accepted 30 November 2004

\begin{abstract}
Concentrations of essential (copper, iron, manganese, selenium, and zinc) and non-essential (arsenic, cadmium, mercury, and lead) trace elements were measured in arms of Octopus vulgaris. The cephalopods were sampled from commercial fishery landings at two sites on the Portuguese coast in spring 2002 and 2003. Mercury was determined using an Advanced Mercury Analyser Spectrophotometer (AMAS) and other trace elements were measured using inductively coupled plasma-atomic emission spectrometry (ICP-AES). Since high levels of arsenic were detected, identification of the forms present was carried out using high performance liquid chromatography (HPLC) followed by ICP-MS.

Mean concentrations of trace elements analysed were in the following order: $\mathrm{As}>\mathrm{Zn}>\mathrm{Fe}>\mathrm{Cu} \gg \mathrm{Cd}>\mathrm{Pb}>$ $\mathrm{Se}>\mathrm{Mn} \gg \mathrm{Hg}$. The results of speciation of arsenic demonstrate that virtually all arsenic was in the arsenobetaine form, which is the less toxic form. The concentrations of several trace elements were generally high in samples from Viana in 2002. Cadmium concentrations were above the legal limit for human consumption in samples from Viana in 2002 and two of these animals also had lead concentrations that exceeded legal limits. Mercury appeared in all samples but levels were within legally defined safe limits. No relationship was detected between trace element concentrations and size or maturity of octopus. (C) 2005 Elsevier Ltd. All rights reserved.
\end{abstract}

Keywords: Cephalopods; Metals; Bioaccumulation; Contamination; Human exposure

\footnotetext{
${ }^{*}$ Corresponding author. Tel.: +351 214836110; fax: +351 213969293.

E-mail addresses: sonia.seixas@oinetspeed.pt,sonia@univab.pt (S. Seixas), pbustama@univ-lr.fr (P. Bustamante), g.j.pierce@abdn.ac.uk (G.J. Pierce).

1 Tel./fax: +33 546500294 .

2 Tel.: +44 1224 272459; fax: +44 1224272396.
}

\section{Introduction}

Like several other cephalopod species, the common octopus Octopus vulgaris is part of the traditional diet of coastal communities in southern Europe. In Portugal, O. vulgaris is an important target species in fisheries and has a high economic, social and cultural value. Therefore, contaminant levels in cephalopods are also of direct concern to public health.

Several studies have revealed that cephalopods have the capacity to accumulate trace elements at high levels 
in their tissues (e.g. Miramand and Bentley, 1992; Bustamante, 1998; Bustamante et al., 1998a,b, 2000, 2002a,b; Storelli and Marcotrigiano, 1999). Among tissues, the digestive gland and branchial hearts appeared to play a major role in bioaccumulation processes of toxic elements such as cadmium and silver, which are detoxified and sequestrated, sometimes over a very long time scale (Bustamante et al., 2002a, 2004; Beuerlein et al., 2002). In general, feeding is considered to be the primary pathway for trace element bioaccumulation in cephalopods and second seawater. Although O. vulgaris is benthic, living in direct contact with the substratum, which represents zanother possible pathway for trace element accumulation.

$O$. vulgaris can therefore constitute a significant source of essentials elements for man but also represents a source of exposure to toxic elements. Thus, there is a need to assess the trace element concentrations in their tissues. Although the highest concentrations of metals may be found in digestive glands of cephalopods (e.g. Miramand and Bentley, 1992; Bustamante et al., 2000), muscular parts, i.e. arms and mantle, are the most commonly eaten by humans and the total amount of toxic elements in these tissues may still be significant.

Only a few studies investigating elements concentrations in octopus from Portugal have been published to date (Seixas et al., 2002, in press; Raimundo et al., 2004). In the former article, the technique used for lead analyses (i.e. particle-induced X-ray emission), did not allow the quantification of this metal in octopus arms (Seixas et al., 2002). Secondly, the others studies were limited to a single period (i.e. 2003, Raimundo et al., 2004) or to a low number of elements (only $\mathrm{Hg}$, Seixas et al., in press). Finally, the bioaccumulation and distribution between tissues of various trace elements in octopus from Portuguese waters have been also studied (Seixas and Pierce, in press, submitted). Therefore, there is a need to provide more data on trace element concentrations in edible tissue of octopus to better evaluate the intake of human populations feeding on this cephalopod. Thus, the present study brings together data on nine different essential and non-essential trace elements in edible tissues (the muscular arms) of octopus $O$. vulgaris collected over two years (2002 and 2003) from two sites on the Portuguese coast, in more and less polluted areas. In addition to examining geographical and interannual differences in concentrations, relationships between levels of different elements, and variation in levels in relation to sex and maturity, were examined.

\section{Material and methods}

\subsection{Sampling and sample preparation}

Octopus were sampled from commercial fishery landings in Cascais, which situated mid-way down the coast of Portugal, with a strong influence of the Tagus River (the largest river in Portugal), and in Viana do Castelo, situated in the north of the Portugal and influenced by freshwater flows into the Rías Gallegas (NW Spain) and the rivers closer to the area (Lima river and Minho river) (Fig. 1).

Octopuses were sampled in spring of 2002 and of 2003, 3 females and 3 males from each area in each year. Results for mercury in arm samples from 2002 were previously used in a comparison of levels in different tissues (digestive gland, branchial hearts, gills, mantle, arms and gonads; Seixas et al., in press).

Fresh animals were taken back to the laboratory and dissected. Total length, mantle length, total weight, sex and maturation state were determined in each animal. The maturation state was evaluated by direct observation of colours of reproductive structures (Gonçalves, 1993). The maturity index used was from Guerra (1975) and is based on microscopic analyses and measurements of ovules and spermatophores. Gonad weights and digestive gland weights were expressed as percentages of total body weight, i.e. as gonadosomatic (GSI) and digestive gland (DGI; see Silva et al., 2002) indices, respectively.

Samples of arm, a piece of around $10 \mathrm{~g}$ were taken from each animal. Prior to the determination of the concentrations of trace elements, all these samples were stored frozen (between $-20{ }^{\circ} \mathrm{C}$ to $-40{ }^{\circ} \mathrm{C}$ ) in individual plastic bags. Samples were then freeze-dried, and reduced to a powder using a porcelain mortar and pestle.

\subsection{Analytical procedure to determine mercury}

For mercury analysis, two aliquots ranging from 10 to $20 \mathrm{mg}$ of dried material were analysed directly in an AMAS (Advanced Mercury Analyser Spectrophotometer), Altec AMA 254. Hg determination involved evaporation of mercury by progressive heating to $800{ }^{\circ} \mathrm{C}$ in an oxygen atmosphere for $3 \mathrm{~min}$ and subsequent amalgamation on a gold-net. The net was then heated to liberate the collected mercury, which was measured by UV atomic absorption spectrophotometry. Quality assurance was assessed using lobster hepatopancreas TORT-2 (NRCC) and dogfish liver and muscle, DOLT-2 and DORM-2 (NRCC) respectively, as reference materials. These standards were treated and analysed under the same conditions as the octopus samples, and recoveries of mercury ranged from $99 \%$ to $101 \%$. The detection limit, calculated as $3 \mathrm{SD}$ of the mean of eight blanks, was 0.005 for $\mathrm{Hg}\left(\mathrm{mg} \mathrm{kg}^{-1}\right.$ dry wt). Mercury concentrations in octopus arm are also reported in $\mathrm{mg} \mathrm{kg}^{-1}$ dry wt.

\subsection{Analytical procedure to determine other elements}

Arsenic, cadmium, copper, iron, manganese, lead, selenium and zinc concentrations were determined by 


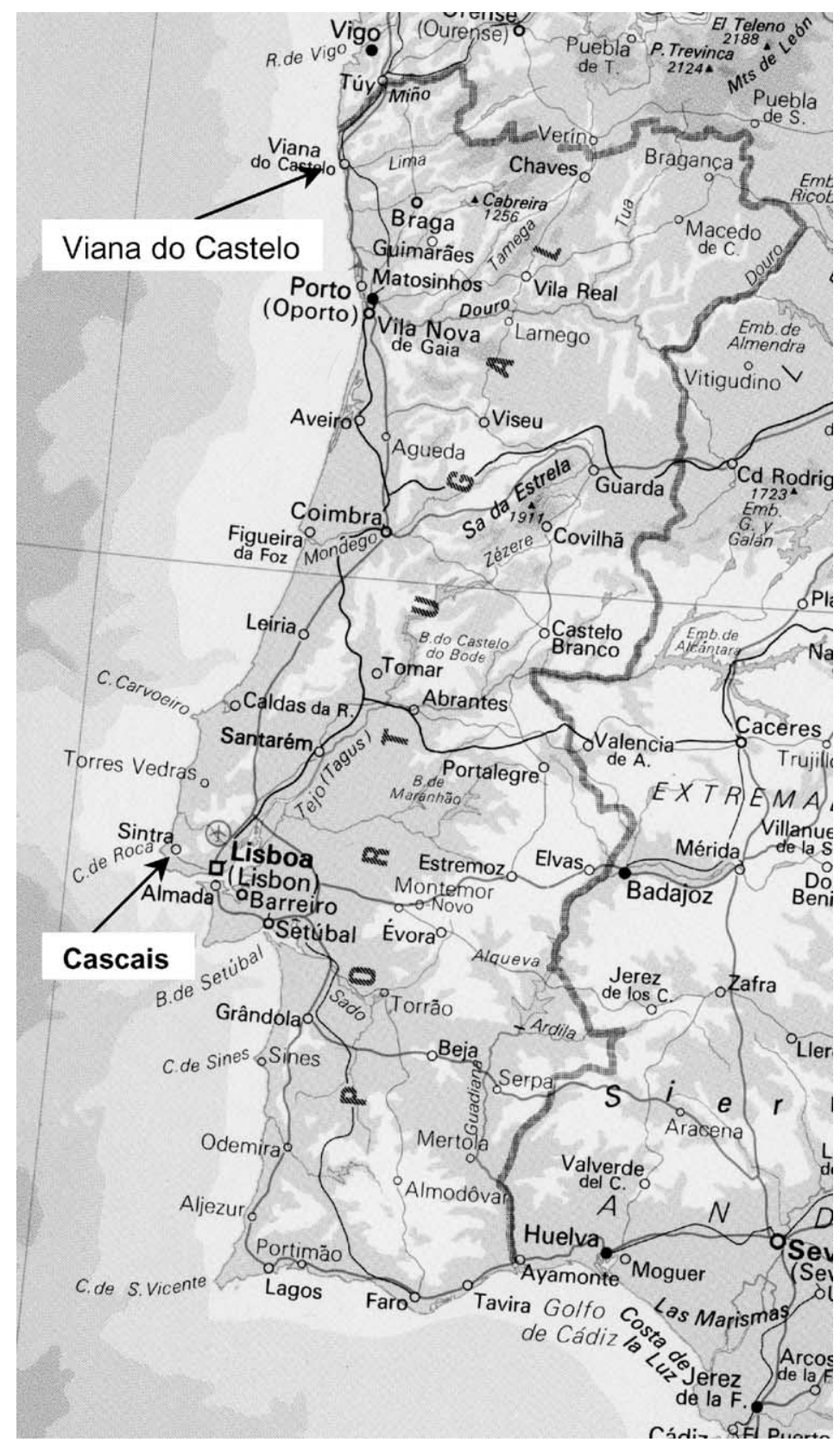

Fig. 1. Map showing locations of the sampling ports.

inductively coupled plasma-atomic emission spectrometry (ICP-AES) after acid digestion with $5 \mathrm{ml}$ of $65 \%$ $\mathrm{HNO}_{3}$ in a microwave then completed to $50 \mathrm{ml}$ with Milli-Q quality water. The same procedure was applied to blanks and reference materials, TORT-2, DOLT-2 and DORM-2. The results for standard reference materials displayed recoveries of the elements ranging from $88 \%$ to $110 \%$. The detection limits were $\left(\mathrm{mg} \mathrm{kg}^{-1}\right.$ dry wt): $8.5(\mathrm{As}), 0.8(\mathrm{Cd}), 0.8(\mathrm{Cu}), 1.7(\mathrm{Fe}), 0.8(\mathrm{Mn}), 0.8$
$(\mathrm{Pb}), 0.8(\mathrm{Se})$ and $1.7(\mathrm{Zn})$. Trace element concentrations in octopus arm are also reported in $\mathrm{m} \mathrm{kg}^{-1}$ dry wt.

\subsection{Analytical procedure for speciation of arsenic}

The speciation of arsenic was determined in samples from Viana and Cascais collected in 2003. A part of each sample was freeze-dried, then powdered with a porcelain mortar and pestle. The other part of each sample was 
homogenised and analysed fresh. The homogenate or powder was then digested with $0.1 \mathrm{~g}$ of trypsin and $10 \mathrm{ml} 0.1 \mathrm{M}$ ammonium bicarbonate for $12 \mathrm{~h}$ in a water bath at $37^{\circ} \mathrm{C}$.

Arsenic speciation was carried out by high performance liquid chromatography (HPLC) follow by inductively coupled plasma-mass spectrometry (ICP-MS). HPLC analysis was carried out on a Varian ProStar, using a Hamilton PRP1 column. For the mobile phase, we used tetrabutylammonium dihydrogenophosphate $0.5 \mathrm{mM}$ and sodium phosphate $4 \mathrm{mM}$. For each run, $20 \mu \mathrm{l}$ of sample was injected, and total time for elution of all species was $15 \mathrm{~min}$.

ICP-MS analysis was carried out on a Varian Ultra Mass 700, with the following settings: plasma flow $15.01 / \mathrm{min}$, auxiliary flow $1.051 / \mathrm{min}$, nebulizer flow $0.90 \mathrm{l} / \mathrm{min}$, sampling depth $7 \mathrm{~mm}$, power $1.30 \mathrm{~kW}$ and pump rate $28 \mathrm{rpm}$. The ultramass ion optical specifications were: extraction lens $-600 \mathrm{~V}$, first lens $-260 \mathrm{~V}$, second lens $-11.80 \mathrm{~V}$, third lens $0 \mathrm{~V}$, fourth lens $-60 \mathrm{~V}$ and photon stop $-11.20 \mathrm{~V}$. The ultramass scan conditions were: points per peak 1 , reading spacing $0.100 \mathrm{AMU}$, and time scan acquisition $10 \mathrm{~ms} /$ point.

\subsection{Statistical procedures}

Statistical analysis was carried out using STATISTICA (StatSoft, Inc., 1995). ANOVA was used to test the influence of sex, year and location on element concentrations in arms. When the level was below the detection limit it was assumed that the concentration was half the detection limit: this was the case for manganese (1 value), selenium (4 values) and cadmium (17 values). Correlations between state of maturation (an ordinal variable) and concentrations in tissues were analysed with the Spearman rank order correlations. To quantify relationships between other parameters (e.g. total length and total weight) and concentrations of elements, the Pearson coefficient of correlation was used. The Ward's Method of tree clustering, which is based on an analysis of variance approach to evaluate the distance between clusters, was used to provide an indication of the overall similarity of different samples. The significance level for statistical analyses was always set at $\alpha=0.05$.

\section{Results}

\subsection{Trace element concentrations in relation to body size and maturation}

There were no significant correlations between concentrations of trace elements in arms of octopus sampled and body length or state of maturation (Table 1). Only in the case of iron was a significant (negative) relation-
Table 1

Pearson's correlations $(R)$, between concentrations of the elements and (a) weight, (b) length; Spearman Rank order correlations $\left(R_{\mathrm{s}}\right)$, between concentrations of the elements and state of maturation

\begin{tabular}{|c|c|c|c|}
\hline Element & Weight & Length & Maturation \\
\hline \multicolumn{4}{|c|}{ Essential elements } \\
\hline $\mathrm{Cu}$ & $-0.15(0.50)$ & $0.01(0.98)$ & $-0.11(0.61)$ \\
\hline $\mathrm{Fe}$ & $-0.41(0.04)$ & $-0.12(0.58)$ & $-0.19(0.38)$ \\
\hline $\mathrm{Mn}$ & $-0.24(0.26)$ & $-0.15(0.50)$ & $0.07(0.74)$ \\
\hline $\mathrm{Se}$ & $-0.10(0.66)$ & $-0.01(0.95)$ & $-0.19(0.38)$ \\
\hline $\mathrm{Zn}$ & $-0.10(0.64)$ & $0.08(0.72)$ & $-0.12(0.59)$ \\
\hline \multicolumn{4}{|c|}{ Non-essential elements } \\
\hline As & $0.02(0.92)$ & $0.10(0.66)$ & $0.02(0.92)$ \\
\hline $\mathrm{Cd}$ & $-0.08(0.70)$ & $0.02(0.93)$ & $-0.18(0.40)$ \\
\hline $\mathrm{Hg}$ & $0.04(0.87)$ & $0.16(0.47)$ & $-0.12(0.57)$ \\
\hline $\mathrm{Pb}$ & $-0.21(0.33)$ & $0.11(0.60)$ & $0.11(0.60)$ \\
\hline
\end{tabular}

Probability values $(p)$ appear in parentheses. Sample size was 24 in all cases. Significant correlations are indicated in bold face.

ship seen between concentration and body weight (Table 1). Given that Table 1 reports 27 correlation coefficients, at least one would be expected to be significant $(p<0.05)$ by chance alone. Thus, while noting the small sample size, the general conclusion is that trace element concentrations are not related to body size or maturation state.

\subsection{Essential elements (copper, iron, manganese, selenium, zinc)}

The average concentrations in octopus arms ranged between 1 and $2 \mathrm{mg} \mathrm{kg}^{-1}$ for selenium, 1.5 and $2.5 \mathrm{mg}$ $\mathrm{kg}^{-1}$ for manganese, 40 and $50 \mathrm{mg} \mathrm{kg}^{-1}$ for iron, 4 and $203 \mathrm{mg} \mathrm{kg}^{-1}$ for copper, and 50 and $300 \mathrm{mg} \mathrm{kg}^{-1}$ for zinc (Fig. 2).

Comparisons between localities of essential trace elements demonstrated significant differences only for selenium (Table 2), although it should be noted that sample sizes were relatively small for all comparisons $(N=24$ animals overall). In 2002 there were higher levels of selenium in the Viana samples $(t=2.44, p=0.04)$ but this difference was not apparent in $2003(t=-2.04, p=$ $0.07)$.

Of the essential elements, only copper and selenium showed significant interannual variation (Table 2). In Viana samples, concentrations were higher in 2002 $(\mathrm{Cu}: t=2.63, p=0.03$; Se: $t=3.95, p<0.01)$. In Cascais samples, the between-year differences for these elements were not significant ( $\mathrm{Cu}: t=0.83, p=0.43$; Se: $t=1.19$, $p=0.27)$.

Iron concentrations were higher in females than in males (Table 2, Fig. 2) but concentrations of the other essential elements were similar in both sexes. 

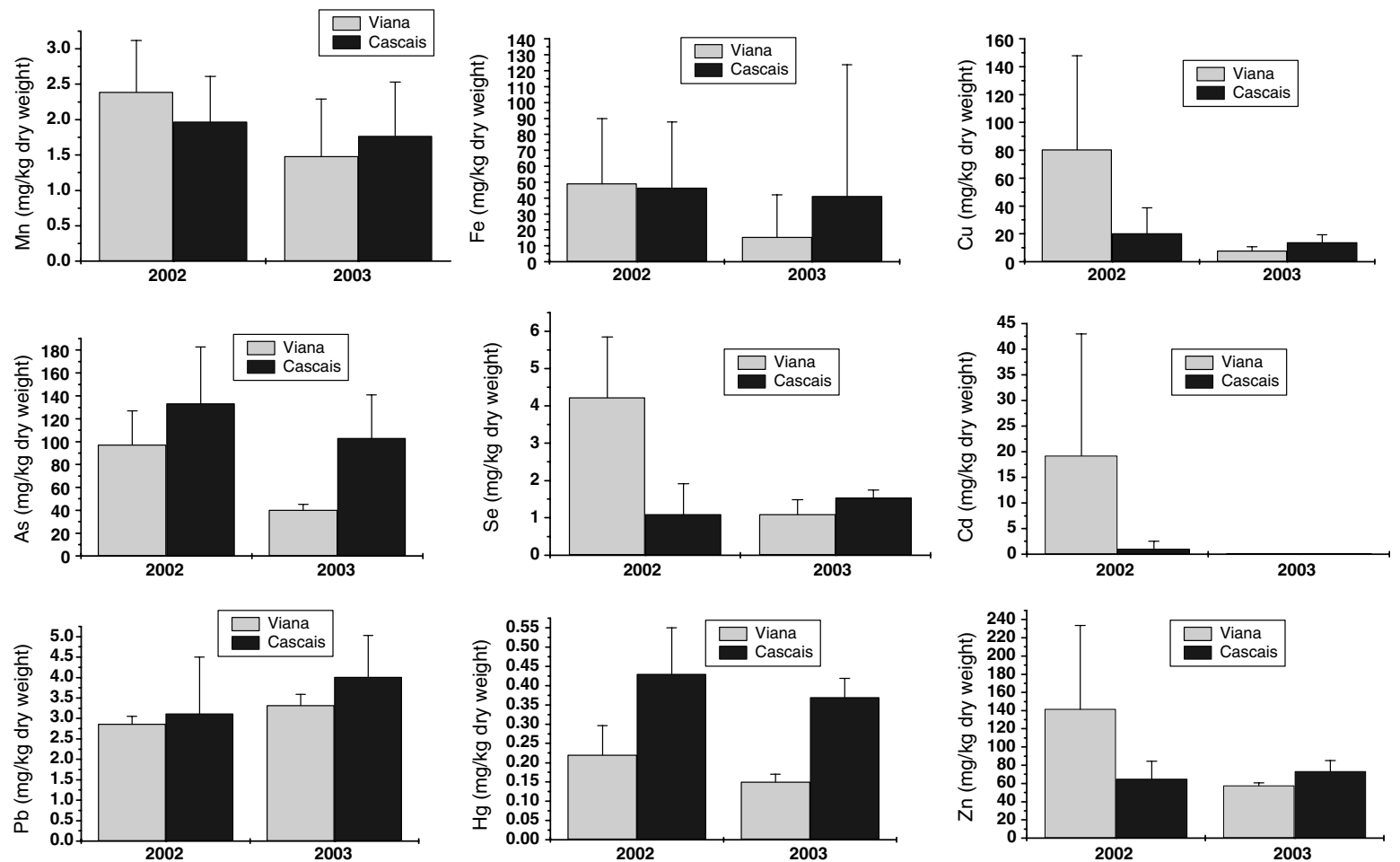

Fig. 2. Concentrations of trace elements ( $\left.\mathrm{mg} \mathrm{kg}^{-1} \mathrm{dry} \mathrm{wt}\right)$ in octopus arms sampled in 2002 and 2003 from Viana and Cascais.

Table 2

Results of ANOVA for effects of locality, year and gender on element concentrations

\begin{tabular}{|c|c|c|c|}
\hline Element & Locality & Year & Gender \\
\hline \multicolumn{4}{|c|}{ Essential elements } \\
\hline $\mathrm{Cu}$ & $4.10(0.06)$ & $7.72(0.01)$ & $0.39(0.54)$ \\
\hline $\mathrm{Fe}$ & $0.02(0.89)$ & $1.242(0.28)$ & $5.56(0.03)$ \\
\hline $\mathrm{Mn}$ & $0.13(0.72)$ & $2.11(0.17)$ & $1.79(0.20)$ \\
\hline $\mathrm{Se}$ & $10.17(0.01)$ & $8.61(0.01)$ & $0.79(0.39)$ \\
\hline $\mathrm{Zn}$ & $2.81(0.11)$ & $4.12(0.06)$ & $0.77(0.39)$ \\
\hline \multicolumn{4}{|c|}{ Non-essential elements } \\
\hline As & $11.88(<0.00)$ & $11.48(<0.00)$ & $0.72(0.41)$ \\
\hline $\mathrm{Cd}$ & $4.35(0.05)$ & $4.99(0.04)$ & $0.75(0.40)$ \\
\hline $\mathrm{Hg}$ & $44.788(<0.00)$ & $5.67(0.034)$ & $2.52(0.13)$ \\
\hline $\mathrm{Pb}$ & $1.64(0.22)$ & $3.59(0.08)$ & $1.76(0.20)$ \\
\hline
\end{tabular}

$F$ values are given, with probability $(p)$ in parentheses. Significant variation is indicated by use of bold face.

\subsection{Non-essential elements (arsenic, cadmium, mercury, lead)}

Although toxic in all but trace amounts, arsenic is normally considered to be an essential element (Anke et al., 1997). However, in cephalopods there is no published information on its role, so it is considered here along with the other non-essential (and toxic) elements.
Cadmium concentrations were higher in 2002 than in 2003. Viana samples from 2002 had an average cadmium concentration of around $20 \mathrm{mg} \mathrm{kg}^{-1}$ while values for the 2003 samples were all below the detection limit (Fig. 2). Cadmium was detected in five out of six animals from Viana in 2002 and in two of the Cascais animals from 2002.

The average concentrations of arsenic, mercury and lead in octopus arms were $40-130 \mathrm{mg} \mathrm{kg}^{-1}, 0.15-$ $0.45 \mathrm{mg} \mathrm{kg}^{-1}$ and $3-4 \mathrm{mg} \mathrm{kg}^{-1}$, respectively (Fig. 2).

Comparisons of non-essential trace elements between localities demonstrated significant differences only for arsenic and mercury. Differences between localities for arsenic were significant in $2003(t=-4.03, p<0.01)$, with higher levels in Cascais samples, but difference was not significant in $2002(t=-1.54, p=0.16)$. Concentrations of mercury were significantly higher in the Cascais samples in both years $(t=-3.46, p=0.01$; $t=-10.57, p<0.01$, respectively).

There were also significant interannual differences in concentrations of arsenic and mercury. In Viana samples, concentrations were higher in 2002 (As: $t=4.63$, $p<0.01$; Hg: $t=2.39, p=0.04$ ), although in Cascais there was no significant difference between years (As: $t=1.19, p=0.26$; Hg: $t=0.97, p=0.35$ ).

To determine the species of arsenic present, we used both dried and fresh samples; both gave identical results. 
The results were also the same for both localities, Viana and Cascais. The chemical form of arsenic was almost 100\% arsenobetaine, while As III (arsenite) and As V (arseniate) were below the detection limit of $5 \mu \mathrm{g}^{-1}$ in all samples.

\subsection{Correlations between different trace elements}

Concentrations of arsenic and mercury were positively correlated, as were those of zinc, cadmium and copper (Table 3). Selenium concentrations were correlated with those of copper, manganese, zinc and cadmium. Iron concentrations were correlated with those of manganese and lead.

Most of these relationships also emerge from the Ward's diagram (Fig. 3), notably the close relationship between cadmium, copper and zinc (see also Fig. 4), although lead and iron are in different halves of the classification.

Table 3

Significant (Pearson) correlations between concentrations of different elements

\begin{tabular}{ll}
\hline Elements & Correlation \\
\hline $\mathrm{As}$ & $+\mathrm{Hg}^{* * *}$ \\
$\mathrm{Cd}$ & $+\mathrm{Cu}^{* * *},+\mathrm{Zn}^{* * *},+\mathrm{Se}^{* * *}$ \\
$\mathrm{Cu}$ & $+\mathrm{Cd}^{* * *},+\mathrm{Se}^{* * *},+\mathrm{Zn}^{* * *}$ \\
$\mathrm{Fe}$ & $+\mathrm{Mn}^{* * *},+\mathrm{Pb}^{* *}$ \\
$\mathrm{Hg}$ & $+\mathrm{As}^{* * *}$ \\
$\mathrm{Mn}$ & $+\mathrm{Fe}^{* * *},+\mathrm{Se}^{*}$ \\
$\mathrm{~Pb}$ & $+\mathrm{Fe}^{* *}$ \\
$\mathrm{Se}$ & $+\mathrm{Cu}^{* * *},+\mathrm{Mn}^{*},+\mathrm{Zn}^{* * *},+\mathrm{Cd}^{* * *}$ \\
$\mathrm{Zn}$ & $+\mathrm{Cd}^{* * *},+\mathrm{Cu}^{* * *},+\mathrm{Se}^{* * *}$ \\
\hline${ }^{*} p<0.05$. & \\
${ }^{* *} p<0.01$. & \\
${ }^{* * *} p<0.005$. &
\end{tabular}

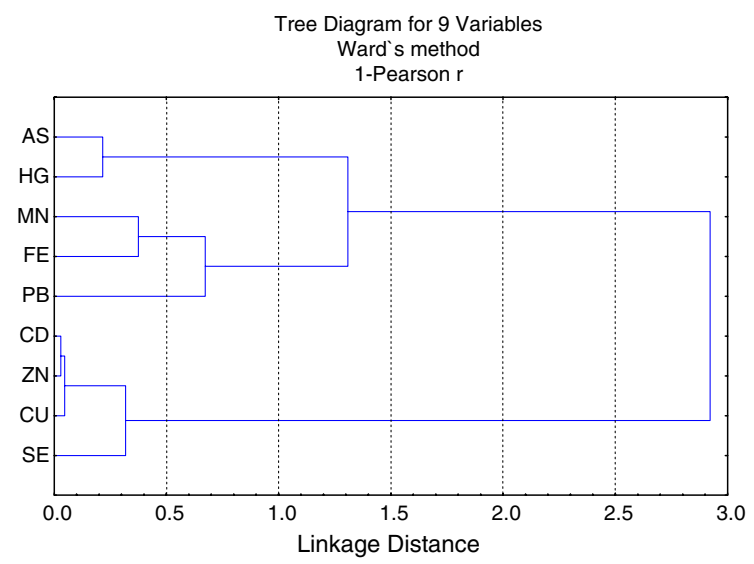

Fig. 3. Ward's method tree diagram for the trace elements analysed in arms of octopus from Portugal.

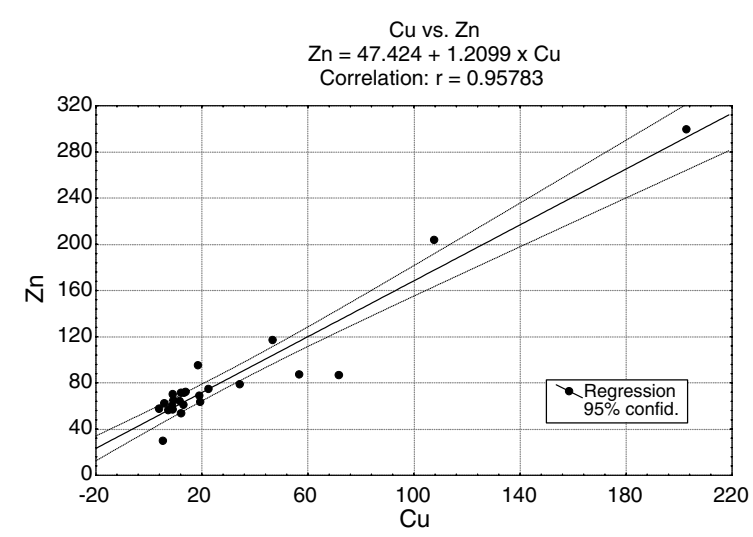

Fig. 4. Regression relationship between copper and zinc concentrations ( $\mathrm{mg} \mathrm{kg}^{-1}$ dry wt) in arms of Octopus vulgaris from Portugal.

\section{Discussion}

\subsection{Essential elements}

The concentrations of the essential elements - copper, iron, manganese, selenium and zinc_-varied over two order of magnitude, with the lowest average concentrations for manganese and selenium below $2.5 \mathrm{mg} \mathrm{kg}^{-1}$ and the highest for zinc reaching up $70 \mathrm{mg} \mathrm{kg}^{-1}$, and the following overall pattern of relative concentrations: $\mathrm{Se} \approx \mathrm{Mn}<\mathrm{Cu}<\mathrm{Fe}<\mathrm{Zn}$. These essential elements are thought to be regulated by homeostatic processes.

Manganese is involved in protein, lipid and carbohydrate metabolism (NAS, 2002), is a cofactor for enzymes (particularly those involved in phosphorylation), and is involved in glycolysis and the synthesis of cholesterol, DNA, RNA and fatty acids (Bowen, 1979; Goyer, 1995; Barceloux, 1999a; Roth, 2003). It is also essential to the activity and development of nervous tissues (Ledig et al., 1991). Iron is a component of a number of proteins such as ferritin (Nardi et al., 1971; NAS, 2000, 2002). Copper is an important component of respiratory pigment hemocyanin (Barceloux, 1999b). Indeed, $85 \%$ of the total copper in O. vulgaris is bound to this respiratory pigment (D'Aniello et al., 1986) and hemocyanin represents $98 \%$ of the blood proteins in cephalopods (Ghiretti, 1966). Zinc acts as a cofactor in a variety of cellular processes, including DNA synthesis (Barceloux, 1999c). Selenium is a component of glutathione peroxidase, which is an important enzyme for processes that protect lipids in polyunsaturated membranes from oxidative degradation (Barceloux, 1999d).

However, the concentrations of trace elements could also vary in relation to several endogenous (biological) and exogenous (environmental) factors. Among them, the sex of the animal is likely to be one of the most important. However, in our study, the concentrations 
of essential elements did not vary significantly with gender, except for iron. Indeed, female octopuses exhibited higher iron concentrations independently of the year or the area. This result is difficult to explain but might be link to different metabolic needs in relation to egg production.

Comparison of essential trace element concentrations in octopus from different localities showed significant differences only for selenium. Octopus from Viana in 2002 were characterised by relatively high and variable concentrations of selenium compared to those from Cascais. However, our values for the other samples were quite similar to values recorded in squid from the English Channel (see Table 4).

The values for selenium obtained in the present study were broadly in line with results from samples of $O$. vulgaris from three localities on the Portuguese coast in 1999-2000 (Seixas and Pierce, in press). Published data for other cephalopods refer to concentrations of elements per unit wet weight. For octopus arms the normal ratio of wet weight to dry weight is approximately 5:1 (S. Seixas, unpublished data), so our values are rather high compared to those recorded in other cephalopods (see Table 4).

In relation to manganese and iron, again levels were similar to those found in 1999/2000 (Seixas and Pierce, submitted) and all were high compared to published results for cephalopods (Table 4). Our values for copper were somewhat higher than recorded in other cephalopods, although a value equivalent to almost $40 \mathrm{mg} \mathrm{kg}^{-1}$ dry wt has been recorded in squid (Falandysz, 1989). It may be seen that zinc concentrations calculated in the present study were similar to the values found in the same area in 1999/2000 and generally comparable with values recorded for other cephalopods.

\subsection{Non-essential elements}

Levels of arsenic observed in 2002 did not differ between localities but in 2003 there were differences between Viana and Cascais. 2003 was a year with important floods that could have moved a large amount of sediment from the Tagus estuary to the adjacent coast (S. Seixas, personal observation). In fact, one of the major inputs of arsenic to the marine environment is river runoff (WHO, 2001).

The toxicity of arsenic depends on the chemical form. In order of decreasing toxicity, the common forms are: arsenite $(+3)$, arsenate $(+5)$, dimethylarsinic acid (DMA), monomethylarsonic acid (MMA, MSMA), arsenobetaine, arsenocholine and trimethylarsine oxide (Hamasaki et al., 1995). The chemical form of arsenic recorded in the present study was almost $100 \%$ arsenobetaine, while As III (arsenite) and As V (arseniate) were below the detection limit of $5 \mu \mathrm{g}^{-1}$ in all samples. In most marine animals, arsenobetaine $\left(\left(\mathrm{CH}_{3}\right)_{3} \mathrm{As}+\mathrm{CH}_{2^{-}}\right.$
$\mathrm{COO}^{-}$) is the sole or major arsenic compound, with other organo-arsenic compounds and inorganic arsenic generally occurring as minor constituents (Francesconi and Edmonds, 1997). Arsenobetaine plays an important role in accumulation of arsenic in the trophic chain $(\mathrm{Ku}-$ bota et al., 2003). The transformation by animals of other forms of arsenic into arsenobetaine can be a mechanism of detoxification, because arsenobetaine is not found in seawater. The mechanism of this transformation is, however, not clear (Bettencourt, 1990). The dominant form of arsenic in oxygenated marine and brackish waters is arsenate, which is very toxic (Neff, 1996).

The other non-essential elements measured in this study are toxic to the organisms. In fact cadmium $\left(\mathrm{Cd}^{2+}\right)$ is known to be able to substitute for $\mathrm{Zn}^{2+}$ (WHO, 1992). In living animals, cadmium is transported to the liver or equivalent structure and induces the synthesis of metallothionein (e.g. George and Viarengo, 1985; Cosson et al., 1991). Continuous synthesis of metallothionein is necessary for the continued sequestration of the cadmium ions (Adams et al., 1993). This association with metallothionein can be considered as a mechanism of cadmium detoxification of the organism (Viarengo and Nott, 1993; Roesijadi, 1996). Mercury is considered to be one of the most problematic metals in marine ecosystems because of its bioaccumulation and biomagnification in marine food webs (EPA, 2001). The predominant form of mercury in seafood is methyl mercury (NAS, 1991). This is the form that is most toxic to organisms, which it provokes deleterious effects in the nervous system and interferes with the process of cell division (Horvat, 2001; Pinho et al., 2002). Lead is a classic chronic or cumulative poison, which produces a continuum of deleterious effects on animals and humans (WHO, 2000). Aquatic organisms take up and accumulate lead from water, sediment or/and food. Lead in water is fixed by lysosomes when water crosses the branchial epithelium of bivalves. When lead in food arrives in the digestive tract, there is immobilisation by interstitial cells and capture by amoebocytes (Amiard, 1988; Galdies and Axiak, 1992). In animals, lead affects a great number of enzymes and physiological systems (WHO, 2000).

The absence of cadmium in detectable amounts in 2003 suggests that cadmium contamination may be localised in space or time; clearly further sampling is needed to fully understand the extent of contamination in the fished octopus population, particularly in the Viana area. Studies carried out by the National Water Institute (INAG) in the same area on mussels, between May and June of 1999, verify that levels were high especially at Viana. In fact the values for cadmium concentration in octopus arms obtained in this study are very high when compared with values in the literature for other cephalopods (Table 4), adding weight to the idea that a local source of contamination is responsible for 
Table 4

Concentration of trace elements $\left(\mathrm{mg} \mathrm{kg}^{-1}\right)$ in arms of cephalopods

\begin{tabular}{|c|c|c|c|c|c|c|c|c|c|c|c|c|c|}
\hline \multirow[t]{2}{*}{ Species } & \multirow[t]{2}{*}{ Locality } & \multirow[t]{2}{*}{ Year } & \multirow{2}{*}{$\begin{array}{l}\text { Sample } \\
\text { size }\end{array}$} & \multicolumn{5}{|c|}{ Essential elements } & \multicolumn{4}{|c|}{ Non-essential elements } & \multirow[t]{2}{*}{ Authors } \\
\hline & & & & $\mathrm{Cu}$ & $\mathrm{Fe}$ & $\mathrm{Mn}$ & $\mathrm{Se}$ & $\mathrm{Zn}$ & As & $\mathrm{Cd}$ & $\mathrm{Hg}$ & $\mathrm{Pb}$ & \\
\hline $\begin{array}{l}\text { Octopus } \\
\quad \text { vulgaris }\end{array}$ & $\begin{array}{l}\text { Viana do } \\
\text { Castelo }\end{array}$ & 2002 & 6 & $81 \pm 68$ & $49 \pm 41$ & $2.39 \pm 0.72$ & $4.2 \pm 1.6$ & $142 \pm 92$ & $97 \pm 30$ & $19 \pm 24$ & $0.22 \pm 0.08$ & $2.9 \pm 0.2$ & Present study \\
\hline $\begin{array}{l}\text { Octopus } \\
\text { vulgaris }\end{array}$ & $\begin{array}{l}\text { Viana do } \\
\text { Castelo }\end{array}$ & 2003 & 6 & $7.9 \pm 2.9$ & $15 \pm 27$ & $1.5 \pm 0.8$ & $1.1 \pm 0.4$ & $58 \pm 3$ & $40 \pm 5$ & $0.4 \pm 0.0$ & $0.15 \pm 0.02$ & $3.3 \pm 0.3$ & Present study \\
\hline $\begin{array}{l}\text { Octopus } \\
\text { vulgaris }\end{array}$ & Cascais & 2002 & 6 & $20 \pm 18$ & $47 \pm 41$ & $1.97 \pm 0.64$ & $1.1 \pm 0.8$ & $65 \pm 19$ & $133 \pm 49$ & $1.2 \pm 1.4$ & $0.43 \pm 0.13$ & $3.1 \pm 1.4$ & Present study \\
\hline $\begin{array}{l}\text { Octopus } \\
\text { vulgaris }\end{array}$ & Cascais & 2003 & 6 & $14 \pm 5.5$ & $41 \pm 83$ & $1.76 \pm 0.77$ & $1.5 \pm 0.20$ & $74 \pm 12$ & $103 \pm 38$ & $0.4 \pm 0.0$ & $0.37 \pm 0.04$ & $4.0 \pm 1.0$ & Present study \\
\hline $\begin{array}{l}\text { Octopus } \\
\text { vulgaris }\end{array}$ & $\begin{array}{l}\text { Viana do } \\
\text { Castelo }\end{array}$ & $\begin{array}{l}1999 / \\
2000\end{array}$ & 10 & $27 \pm 15$ & $15 \pm 4$ & $1.44 \pm 0.60$ & $1.3 \pm 0.4$ & $78 \pm 24$ & $34 \pm 14$ & & & & $\begin{array}{l}\text { Seixas and Pierce } \\
\text { (in press, } \\
\text { submitted) }\end{array}$ \\
\hline $\begin{array}{l}\text { Octopus } \\
\text { vulgaris }\end{array}$ & Cascais & $\begin{array}{l}1999 / \\
2000\end{array}$ & $20-40$ & $33 \pm 19$ & $28 \pm 19$ & $2.15 \pm 0.81$ & $1.2 \pm 0.6$ & $69 \pm 21$ & $62 \pm 28$ & & & & $\begin{array}{l}\text { Seixas and Pierce } \\
\text { (in press, } \\
\text { submitted) }\end{array}$ \\
\hline $\begin{array}{l}\text { Octopus } \\
\text { vulgaris }\end{array}$ & $\begin{array}{l}\text { Santa } \\
\text { Luzia }\end{array}$ & $\begin{array}{l}1999 / \\
2000\end{array}$ & 20 & $59 \pm 77$ & $30 \pm 44$ & $1.85 \pm 1.99$ & $0.9 \pm 0.3$ & $40 \pm 24$ & $15 \pm 10$ & & & & $\begin{array}{l}\text { Seixas and Pierce } \\
\text { (in press, } \\
\text { submitted) }\end{array}$ \\
\hline $\begin{array}{l}\text { Octopus } \\
\text { vulgaris }\end{array}$ & $\begin{array}{l}\text { Tyrrhenian } \\
\text { Coast }\end{array}$ & - & 5 & & & & & & & & $1.65 \pm 0.64 * a$ & & $\begin{array}{l}\text { Renzoni et al. } \\
\text { (1973) }\end{array}$ \\
\hline $\begin{array}{l}\text { Octopus } \\
\text { vulgaris }\end{array}$ & $\begin{array}{l}\text { Kastela Bay } \\
\text { (Adriatic) }\end{array}$ & - & NM & & & & & & & & $0.52 \mathrm{a}$ & & $\begin{array}{l}\text { Buzina et al. } \\
\text { (1989) }\end{array}$ \\
\hline $\begin{array}{l}\text { Octopus } \\
\text { vulgaris }\end{array}$ & $\begin{array}{l}\text { Modena } \\
\text { (Italy) }\end{array}$ & - & 3 & & & & & & & & $0.04 *$ & & $\begin{array}{l}\text { Plessi et al. } \\
\text { (2001) }\end{array}$ \\
\hline $\begin{array}{l}\text { Octopus } \\
\text { vulgaris }\end{array}$ & $\begin{array}{l}\text { Japan } \\
\text { (Pacific } \\
\text { Ocean) }\end{array}$ & $\begin{array}{l}1977 / \\
1978\end{array}$ & 19 & $2.5 * \mathrm{~b}$ & $1.8 * \mathrm{~b}$ & $0.33 * b$ & & $14 * \mathrm{~b}$ & & & & & $\begin{array}{l}\text { Ueda et al. } \\
\text { (1979) }\end{array}$ \\
\hline $\begin{array}{l}\text { Paroctopus } \\
\text { dofleini }\end{array}$ & $\begin{array}{l}\text { Japan } \\
\text { (Pacific } \\
\text { Ocean) }\end{array}$ & $\begin{array}{l}1977 / \\
1978\end{array}$ & 16 & $4.0 * \mathrm{~b}$ & $1.4 * b$ & $0.17 * b$ & & $13 * b$ & & & & & $\begin{array}{l}\text { Ueda et al. } \\
\text { (1979) }\end{array}$ \\
\hline $\begin{array}{l}\text { Benthoctopus } \\
\quad \text { thielei }\end{array}$ & Kerguelen & $\begin{array}{l}1994 / \\
1995\end{array}$ & 17 & $3 \mathrm{a}$ & & & & $138 \mathrm{a}$ & & $0.21 \mathrm{a}$ & & & $\begin{array}{l}\text { Bustamante } \\
\text { (1998) }\end{array}$ \\
\hline $\begin{array}{l}\text { Doryteuthis } \\
\text { bleekeri }\end{array}$ & $\begin{array}{l}\text { Japan } \\
\text { (Pacific } \\
\text { Ocean) }\end{array}$ & $\begin{array}{l}1977 / \\
1978\end{array}$ & 20 & $1.3 * \mathrm{~b}$ & $2.8 * \mathrm{~b}$ & $0.12 * b$ & & $8 * \mathrm{~b}$ & & & & & $\begin{array}{l}\text { Ueda et al. } \\
\text { (1979) }\end{array}$ \\
\hline $\begin{array}{c}\text { Sthenoteuthis } \\
\text { bartrami }\end{array}$ & $\begin{array}{l}\text { Japan } \\
\text { (Pacific } \\
\text { Ocean) }\end{array}$ & $\begin{array}{l}1977 / \\
1978\end{array}$ & 64 & $2.6 * b$ & $1.8 * \mathrm{~b}$ & $0.13 * b$ & & $14 * \mathrm{~b}$ & & & & & $\begin{array}{l}\text { Ueda et al. } \\
\text { (1979) }\end{array}$ \\
\hline $\begin{array}{l}\text { Concentration } \\
\text { Loligo } \\
\quad \text { patagonica }\end{array}$ & $\begin{array}{l}\text { trace elements } \\
\text { Argentina }\end{array}$ & $\begin{array}{c}\left(\mathrm{mg} \mathrm{kg}^{-}\right. \\
1986\end{array}$ & ) in $\operatorname{arr}$ & $\begin{array}{l}\text { in our st } \\
7.8^{*}\end{array}$ & $\begin{array}{l}y \text { and for } \\
2.3^{*}\end{array}$ & $\begin{array}{l}\text { for other au } \\
0.45^{*}\end{array}$ & $\mathrm{~s}$ in cepl & $\begin{array}{l}\text { opods in } \\
12^{*}\end{array}$ & wt & $0.32 *$ & & & $\begin{array}{l}\text { Falandysz } \\
\text { (1989) }\end{array}$ \\
\hline
\end{tabular}




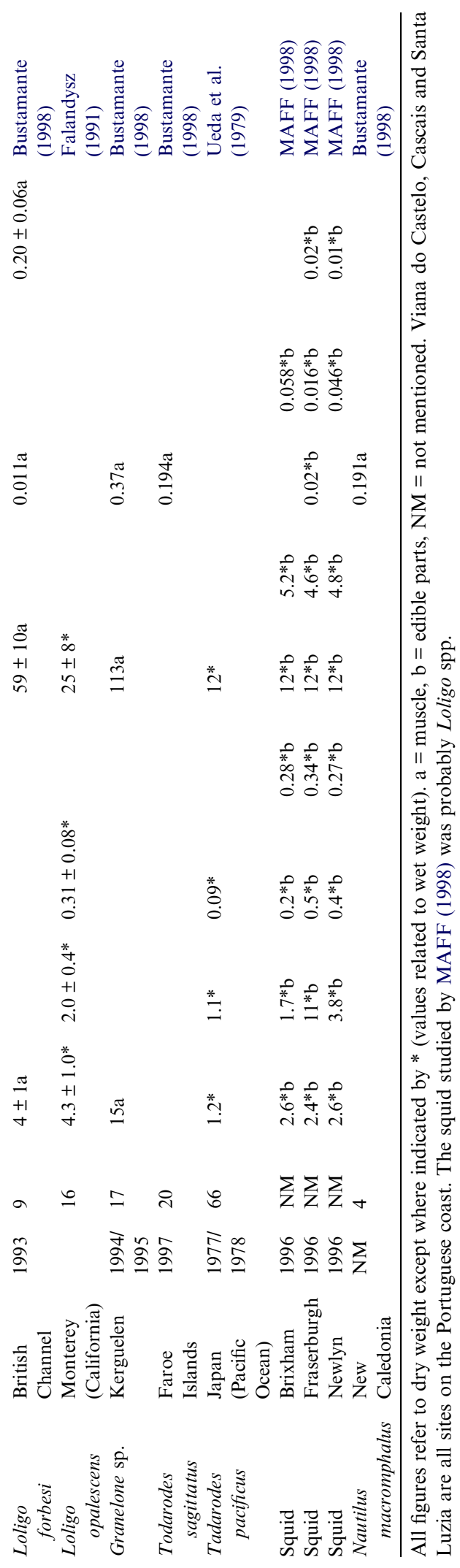

the general increase of $\mathrm{Cd}$ concentrations in molluscs from this area.

Mercury concentrations for this species reported in the literature (Table 4) range from values considerably lower than recorded in the present study (Plessi et al., 2001) to around an order of magnitude higher (once corrected to refer to dry weight; Renzoni et al., 1973). There were few references in literature about levels of lead in arms of cephalopods, although results from squid (probably Loligo spp.) from the English Channel indicate a concentration at least an order of magnitude lower than that recorded here (Table 4).

\subsection{Correlations between concentrations of different trace elements}

The association between manganese and iron in the octopus was evident from the Ward's diagram (Fig. 3). Manganese and iron have synergistic effects: the absorption of iron depends on manganese although the concentration of manganese is frequently lower than iron (Roth, 2003). There were no significant differences between localities and years in concentrations of either manganese or iron.

Concentrations of cadmium, copper and zinc were all positively correlated with each other (Table 3 ). Such correlations between these elements have been noted by various including in other studies on cephalopods (Bustamante, 1998; Bustamante et al., 2002a,b). These correlations can be explained by the high affinity that copper demonstrates for proteins responsible for the regulation of zinc, the metallothioneins (Viarengo, 1989). Cadmium also demonstrates a great affinity to metallothioneins, which provides a mechanism for detoxification of the animals (Cosson et al., 1991). Consequently, cadmium behaves more like essential element than like a toxic element (Fig. 3).

There was a positive correlation between concentrations of selenium and cadmium. Selenium has been reported to be involved in the detoxification processes of several metals, e.g. cadmium, copper, mercury and silver, allowing the formation of insoluble complexes of metal-selenide (Goyer, 1995). A correlation between concentrations of selenium and cadmium in mantle tissue of the octopus Eledone cirrhosa (Barghigiani et al., 1993) was interpreted for the presence of protection mechanism based on the formation of a Cd-Se complex and subsequent release from the body. Thus selenium may also have a role in detoxification of cadmium in O. vulgaris.

\subsection{Concern for public health}

Based on the present results, arsenic is not a concern to humans who consume octopus from Portuguese 
coastal waters, because arsenobetaine is known to be rapidly excreted into urine in humans and is both metabolically inert and non-toxic (Fodor, 2001; Urieta et al., 2001).

Concentrations of cadmium in octopus arm samples from Viana were higher than the maximum levels of this metal allowed for human consumption, namely $1.0 \mathrm{mg} \mathrm{kg}^{-1}$ wet weight (EC rule no. 466/2001), which corresponds (in octopus arm tissue) to $5.0 \mathrm{mg} \mathrm{kg}^{-1}$ dry wt. This level or higher occurred in 4 out of 5 animals in which cadmium was detected in 2002. Further studies are needed to assess the risk of octopus consumption by Portuguese people, particularly considering the chemical form of cadmium in octopus arms.

Maximum levels of mercury allowed for human consumption are $0.5 \mathrm{mg} \mathrm{kg}^{-1}$ fresh weight (EC, rule no. 466/2001), which corresponds (in arm tissue) to $2.5 \mathrm{mg} \mathrm{kg}^{-1}$ dry wt. Portugal signed the Paris convention, under which it was established that the maximum level of mercury in animals for human consumption is $0.3 \mathrm{mg} \mathrm{kg}^{-1}$ fresh weight, which corresponds to approximately $1.5 \mathrm{mg} \mathrm{kg}^{-1}$ dry wt. The levels of mercury in our study were rather high but below the permitted limit. The highest value in this study was $0.56 \mathrm{mg} \mathrm{kg}^{-1}$ dry wt. The fact that this species can accumulate mercury to concentrations well above safe limits has been shown previously by Renzoni et al. (1973) for O. vulgaris from the Tyrrhenian Sea, who recorded an average concentration in muscle of $1.65 \mathrm{mg} \mathrm{kg}^{-1}$ wet weight, roughly equivalent to $8 \mathrm{mg} \mathrm{kg}^{-1}$ dry wt.

Maximum levels of lead allowed in food for human consumption are $1.0 \mathrm{mg} \mathrm{kg}^{-1}$ wet weight (EC rule no. 466/2001), which corresponds (in arm tissue) to $5.0 \mathrm{mg} \mathrm{kg}^{-1}$ dry wt. Among the concentrations of lead determined in this study, two values were above this limit: $5 \mathrm{mg} \mathrm{kg}^{-1}$ dry wt was recorded in an octopus from Cascais in 2002 and $6.0 \mathrm{mg} \mathrm{kg}^{-1}$ dry wt was recorded in an animal from Cascais in 2003. Again there seems to be the potential for harmful effects, although focused on Cascais rather than Viana, and further study is needed.

\subsection{Conclusion}

Our study provided new data on element trace concentrations in edible arm tissue of the commonly eaten O. vulgaris from Portugal and clearly demonstrated the need to take into account the chemical form of the elements when aiming to evaluate the risk for human consumption. Indeed, despite relatively high levels of arsenic, this element was mainly present under a nontoxic form, i.e. arsenobetaïne. In the same way, further analyses concerning the speciation of cadmium and lead are needed to determine their bioavailability to consumers as some specimens could exhibit concentrations exceeding the limit values fixed by the European Community for those metals.

\section{Acknowledgment}

We are grateful to M. Robert and C. Churlaud of the "Centre Commun d'Analyses" (Université de La Rochelle) for their help in the analyses. Statistical analysis and writing up of this work was supported by the European Commission, under the CEPHSTOCK project (QOL-2001 00962).

\section{References}

Adams, M., Bolger, M., Carrington, C., Coker, C., Cramer, G., DiNovi, M., Dolan, S., 1993. Guidance Document for Cadmium in Shellfish. Centre for Food Safety and Applied Nutrition, Washington.

Amiard, J., 1988. Les mécanismes de transfert des éléments métalliques dans la chaîne alimentaire aboutissant à l' huître et à la moule, mollusques filtreurs, formes chimiques de stockage, conséquences écotoxicologiques. Oceanis 14, 283287.

Anke, M., Glei, M., Arnhold, W., Dobner, C., Seifert, M., 1997. Arsenic. In: O'Dell, B., Sunde, R. (Eds.), Handbook of Nutritionally Essential Mineral Elements. Marcel Dekker, Inc., New York, pp. 631-639.

Barceloux, D., 1999a. Manganese. J. Toxicol., Clin. Toxicol. 37, 293-307.

Barceloux, D., 1999b. Copper. J. Toxicol., Clin. Toxicol. 37, 217-230.

Barceloux, D., 1999c. Zinc. J. Toxicol., Clin. Toxicol. 37, 279292.

Barceloux, D., 1999d. Selenium. J. Toxicol., Clin. Toxicol. 37, 145-172.

Barghigiani, C., D’Ulivo, A., Zamboni, R., Lampugnani, L., 1993. Interaction between selenium and cadmium in Eledone cirrhosa of the Northern Tyrrhenian Sea. Mar. Pollut. Bull. 26, 212-216.

Bettencourt, A., 1990. Especiação e biogeoquímica do arsénio no estuário do Tejo. Ph.D. Thesis, Universidade de Évora, Évora.

Beuerlein, K., Lohr, S., Westermann, B., Ruth, P., Schipp, R., 2002. Components of the cellular defence and detoxification system of the common cuttlefish Sepia officinalis (Mollusca, Cephalopoda). Tissue Cell 34, 390-396.

Bowen, H., 1979. Environmental Chemistry of the Elements. Academic Press, New York.

Bustamante, P., 1998. Bioaccumulation des éléments traces (métaux et terres rares) chez les mollusques céphalopodes et bivalves pectinidés. Implication de leur biodisponibilité pour le transfert vers les prédateurs. Ph.D. Thesis. Université de La Rochelle, France.

Bustamante, P., Caurant, F., Fowler, S., Miramand, P., 1998a. Cephalopods as a vector for the transfer of cadmium to top marine predators in the north-east Atlantic Ocean. Sci. Total Environ. 220, 71-80. 
Bustamante, P., Chérel, Y., Caurant, F., Miramand, P., 1998 b. Cadmium, copper and zinc in octopuses from Kerguelen Islands, Southern Indian Ocean. Polar Biol. 19, 264-271.

Bustamante, P., Grigioni, S., Boucher-Rodoni, R., Caurant, F., Miramand, P., 2000. Bioaccumulation of 12 trace elements in the tissues of the nautilus Nautilus macromphalus from New Caledonia. Mar. Pollut. Bull. 40, 688-696.

Bustamante, P., Cosson, R.P., Gallien, I., Caurant, F., Miramand, P., 2002a. Cadmium detoxification processes in the digestive gland of cephalopods in relation to accumulated cadmium concentrations. Mar. Environ. Res. 53, 227-241.

Bustamante, P., Teyssié, J.L., Fowler, W., Cotret, O., Danis, B., Miramand, P., Warnau, M., 2002b. Biokinetics of zinc and cadmium accumulation and depuration at different stages in the life cycle of the cuttlefish Sepia officinalis. Mar. Ecol. Prog. Ser. 231, 167-177.

Bustamante, P., Teyssié, J.L., Fowler, W., Cotret, O., Danis, B., Miramand, P., Warnau, M., 2004. Uptake, transfer and distribution of silver and cobalt in tissues of the common cuttlefish Sepia officinalis at different stages of its life cycle. Mar. Ecol. Prog. Ser. 269, 185-195.

Buzina, R., Suboticanec, K., Vukusic, J., Sapunar, J., Antonic, K., Zorica, M., 1989. Effect of industrial pollution on seafood content and dietary intake of total and methylmercury. Sci. Total Environ. 78, 45-57.

Cosson, R.P., Amiard-Triquet, C., Amiard, J.C., 1991. Metallothioneins and detoxification. Is the use of detoxification proteins for MTs a language abuse? Water, Air, Soil Pollut. 57/58, 555-567.

D’Aniello, A., Strazzullo, L., D’Onofrio, G., Pischetola, M., 1986. Electrolytes and nitrogen compounds of body fluids and tissues of Octopus vulgaris Lam. J. Comp. Physiol. 156, 503-509.

EPA, 2001. Water quality criterion for the protection of human health: methylmercury. Office Science and Technology, Office of Water. Washington, 253p.

Falandysz, J., 1989. Trace metal in the raw and tinned squid Loligo patagonica. Food Addit. Contam. 6, 483-488.

Falandysz, J., 1991. Concentrations of trace metals in various tissues of the squid Loligo opalescens and their redistribution after canning. J. Sci. Food Agric. 54, 79-87.

Fodor, P., 2001. Arsenic speciation in the environment. In: Edbon, L., Pitts, L., Cornelis, R., Crews, H., Donard, O., Quevauviller, Ph. (Eds.), Trace Element Speciation for Environment Food and Health. MPG Books Ltd, Cornwall, pp. 196-210.

Francesconi, K., Edmonds, J., 1997. Arsenic and marine organisms. Adv. Inorg. Chem. 44, 147-189.

Galdies, Ch., Axiak, V., 1992. The fate of lead in a benthic bivalve (Venus verrucosa). In: UNEP/FAO/IOC: Proceedings of the UNEP/FAO/IOC workshop on the biological effects of pollutants on marine organisms, Malta, 10-14 September 1991. MAP Technical Reports Series 69, pp. 135-141.

George, S., Viarengo, A., 1985. A model for heavy metal homeostasis and detoxification in mussels. In: Thunrberg, F.J., Calabrese, E., Vernberg, W.B. (Eds.), Marine Pollution and Physiology: Recent Advances. University of South Carolina Press, Columbia, pp. 125-143.

Ghiretti, F., 1966. Molluscan hemocyanins. In: Wilbur, K.M., Yonge, C.M. (Eds.), Physiology of Mollusca, vol. II. Academic Press, London, New York, pp. 233-248.
Gonçalves, J., 1993. Octopus vulgaris Cuvier, 1797 (polvo comum): Sinopse da biologia e exploração. Provas de Aptidão Pedagógica e Científica Universidade dos Açores. Horta.

Goyer, R., 1995. Toxic effects of metals. In: Casarett and Doull's Toxicology. The Basic Science of Poisons, 5th ed. McGraw-Hill, New York, pp. 691-736.

Guerra, A., 1975. Determinación de las diferentes fases del desarrollo sexual de Octopus vulgaris Lamarck, mediante un índice de madurez. Investig. Pesq. 39, 397-416.

Hamasaki, T., Nagase, H., Yoshitada, Y., Sato, T., 1995. Formation, distribution, and ecotoxicity of methylmetals of tin, mercury, and arsenic in the environment. Crit. Rev. Environ. Sci. Technol. 25, 45-91.

Horvat, M., 2001. Mercury-do we know enough? In: Ebdon, L., Pitts, L., Cornelis, R., Crews, H., Donard, O., Quevauviller, Ph.. Trace Element Speciation for Environmental, Food and HealthRoyal Society of ChemistryLondon, UK127-141.

Kubota, R., Kunito, T., Tanabe, S., 2003. Occurrence of several arsenic compounds in the liver of birds, cetaceans, pinnipeds, and sea turtles. Environ. Toxicol. Chem. 22, 12001207.

Ledig, M., Tholey, G., Megias-Megias, L., Kopp, P., Wedler, F., 1991. Combined effects of ethanol and manganese on cultured neurons and glia. Neurochem. Res. 16, 591-596.

MAFF, 1998. Concentrations of metals and other elements in marine fish and shellfish. Food Surveillance Information Sheet 151. Ministry of Agriculture, Food and Fisheries, $13 \mathrm{p}$.

Miramand, P., Bentley, D., 1992. Concentration and distribution of heavy metals in tissues of two cephalopods, Eledone cirrhosa and Sepia officinalis, from the French Coast of the English Channel. Mar. Biol. 114, 407-414.

Nardi, G., Muzii, E., Puca, M., 1971. Ferritin in the hepatopancreas of Octopus vulgaris Lam. Comp. Biochem. Physiol. 40B, 199-205.

NAS, 1991. Seafood Safety. National Academy of Science, Washington.

NAS, 2000. Mineral Tolerance of Domestic Animals, 3rd ed. National Academy Press, Washington.

NAS, 2002. Dietary Reference Intakes for Vitamin A, Vitamin $\mathrm{K}$, Arsenic, Boron, Chromium, Copper, Iodine, Iron, Molybdenum, Nickel, Silicon, Vanadium, and Zinc. National Academy Press, Washington, DC.

Neff, J., 1996. Ecotoxicology of arsenic in the marine environment-review. Environ. Toxicol. Chem. 16, 917-927.

Pinho, A., Guimarães, J., Costa, A., Olavo, A., Valentin, J., 2002. Total mercury in muscle tissue of five shark species from Brazilia offshore waters: effects of feeding habit, sex, and length. Environ. Res. Sect. A 89, 250-258.

Plessi, M., Bertelli, D., Monzani, A., 2001. Mercury and selenium content in selected seafood. J. Food Composit. Anal. 14, 461-467.

Raimundo, J., Caetano, M., Vale, C., 2004. Geographical variation and partition of metals in tissues of Octopus vulgaris along the Portuguese coast. Sci. Total Environ. 325, 71-81.

Renzoni, A., Bacci, E., Falciai, L., 1973. Mercury concentration in water, sediments and fauna of an area of the Tyrrhenian Coast. Rev. Int. Océanogr. Méd. 31-32, 17-45. 
Roesijadi, G., 1996. Metallothionein and its role in toxic metal regulation. Comparat. Biochem. Physiol. 113C, 117-123.

Roth, R., 2003. Iron and manganese. Available from <http:// www.acu-cell.com>.

Seixas, S., Pierce, G.J., in press. Bioaccumulation of copper, zinc, arsenic and selenium in tissues of Octopus vulgaris from the Portuguese coast. Aquat. Liv. Resour.

Seixas, S., Pierce, G.J., submitted. Trace metals (Ti, Mn, Fe, $\mathrm{Co}, \mathrm{Ni}$ and $\mathrm{Mo}$ ) in Octopus vulgaris. Mar. Biol. Res.

Seixas, S., Pinheiro, T., Sousa Reis, C., 2002. Lead in octopus (Octopus vulgaris) in Portugal: A preliminary study. B. Mar. Sci. 72, 1091-1093.

Seixas, S., Bustamante, Pierce, G.J., in press. Accumulation of mercury in the tissues of the common octopus Octopus vulgaris (L.) in two localities on the Portuguese coast. Sci. Total Environ.

Silva, L., Sobrino, I., Ramos, F., 2002. Reproductive biology of the common octopus, Octopus vulgaris Cuvier, 1797 (Cephalopoda: Octopodidae) in the Gulf of Cádiz (SW Spain). B. Mar. Sci. 71, 837-850.

Storelli, M., Marcotrigiano, G., 1999. Cadmium and total mercury in some cephalopods from the South Adriatic Sea (Italy). Food Addit. Contam. 16, 261-265.
Ueda, T., Ankara, M., Ishii, T., Suzuki, Y., Susuki, H., 1979. Amounts of trace elements in marine cephalopods. J. Radiat. Res. 20, 338-342.

Urieta, I., Jalón, M., Macho, M., 2001. Arsenic intake in the Basque Country (Spain): a real need for speciation. In: Edbon, L., Pitts, L., Cornelis, R., Crews, H., Donard, O., Quevauviller, Ph. (Eds.), Trace Element Speciation for Environment Food and Health. MPG Books Ltd., Cornwall, pp. 196-210.

Viarengo, A., 1989. Heavy metals in marine invertebrates: mechanisms of regulation and toxicity at the cellular level. CRC Crit. Rev. Aquat. Sci. 1, 295-317.

Viarengo, A., Nott, J., 1993. Mini-review. Mechanisms of heavy metal cation homeostasis in marine invertebrates. Comp. Biochem. Physiol. 104C, 355-372.

WHO, 1992. Cadmium - environmental aspects. Environmental Health Criteria. 135. World Health Organization, Geneva.

WHO, 2000. Lead. WHO Food Additives Series, 44. World Health Organization, Geneva.

WHO, 2001. Arsenic and arsenic compounds. Environmental Health Criteria. 224. World Health Organization, Geneva. 